\title{
Inna Šteinbuka
}

\section{Summary}

The monograph presents a profound study of raising competitiveness and productivity. Increase in productivity is crucial for Latvia's economic growth, especially given the decline in the working-age population and the sharp rise in labour costs. The development of the most prosperous countries in the European Union shows that productivity growth is the main driver of prosperity.

The team of authors has conducted comprehensive research aimed at providing an overall assessment of the productivity, developing a methodological framework, which could be employed in future assessments of Latvian productivity and competitiveness. The authors have formulated conclusions and recommendations, thus elaborating to policy guidelines.

In order for policy makers to set priorities, act and see visible macroeconomic benefits, there is a need for a clear understanding of the opportunities for increasing productivity. It is also necessary to identify the existing barriers at the level of sectors and enterprises.

In his paper, Vice President of the European Commission Valdis Dombrovskis analyses interconnection between productivity and competitiveness. Low productivity and competitiveness are significant concerns in Latvia. The recent years have seen Latvia falling in the Global Competitiveness Index 
by the World Economic Forum, unlike Estonia, which has risen and remains the Baltic champion, and Lithuania, which has maintained its position. Latvia's particular drawbacks lay in business sophistication and innovation factors.

A good proxy measure of competitiveness is productivity. Productivity has grown in Latvia since the financial crisis (at around 2\%, among the highest in the EU), however, at half the rate it was growing before the crisis. Easy gains from catching up are over and the risks of falling into the "middle-income trap" are multiplying.

Weak innovation performance, a diminishing talent pool due to emigration, and insufficient supply of STEM skills all raise concerns about the economy's ability to expand the share of knowledge-intensive activities. The moderation of the investment rate suggests that there is no "low hanging fruit" left and the country's growth model will need to change by shifting the focus to climbing the global value chains.

To enable this process, the country will need a strategy of investment into research, innovation and human capital. As shown by comparative examples of Netherlands, Singapore and New Zealand, without sustained and reliable funding of the science base, structured, independent and regular expert advice on productivity-related policies and strong academy-industry-government cooperation, there cannot be a "great leap forward" in national competitiveness performance.

The core study of the monograph (O. Baranovs, D. Baranova, G. Bērziñ̌s, and I. Skribāne) provides comprehensive insights into the existing research on productivity in Latvia, identifies the topicality of productivity research, and the factors determining productivity. The authors analyse the dynamics of productivity in Latvia, including sectoral aspects, and provide comparisons with other countries.

The authors have identified main productivity enhancing policies in Latvia:

- ensuring a stable macroeconomic environment;

- improving the quality of the business environment;

- improving the availability and quality of the workforce;

- promoting higher value added production;

- ensuring sustainable development;

- strengthening the competitiveness of Latvian regions and Riga.

The authors discuss each policy domain in detail, and argue that only systemic implementation of all policies and structural reforms can provide a desirable outcome.

Juris Binde, President of "Latvijas Mobilais Telefons" offers a comprehensive analysis of productivity potential in the digital era. The article of Inese Stepina, 
Deputy Director-General of Employers' Confederation of Latvia explains the concept of productivity, its impact on business competitiveness and well-being of citizens in open economies. The author concludes that Latvia, in cooperation with European and international statistical services, should keep track of capital productivity and analyze the impact of invested capital on total productivity. Igors Kasjanovs, senior economist of the Nordic Investment Bank, contributes his vision of productivity as a factor of sustainable development.

In order to promote productivity, and thus boost living standards in the long run, public policies need to focus on improving incentives, capabilities and flexibility within economy. Such policies can be difficult for governments to devise, and even more challenging for them to implement, given pressure group politics and fragmented administrative structures. A strong case exists for establishing institutions that not only help governments identify the right policies, but that can also assist them in countering the pressures against reform. Necessary design features for such institutions include independent governance, transparent processes, and solid research capacity.

In order to increase the global competitiveness of the EU and the Member States, the EU Council in September 2016 decided that the euro area countries should establish national productivity boards. The task of productivity boards is independent, objective and scientifically sound analysis of competitiveness and development of recommendations for policy-makers.

Each country can develop the EU Council-initiated productivity board of at their own discretion. What matters most is that the analysis should be independent, accepted by the academic circles and internationally recognised.

The University of Latvia took a lead, and has established the Latvian Forum for Productivity, Effectiveness, Development, and Competitiveness (LV PEAK). This Forum works as a 'think tank' in order to conduct independent, objective and scientifically sound analysis of competitiveness and policy recommendations for the Latvian government.

The monograph is the first research outcome of the Forum. 